\title{
FAKTOR-FAKTOR YANG MEMPENGARUHI IBU DALAM KEGAGALAN PEMBERIAN ASI EKSKLUSIF
}

\author{
Umi Salamah'1), Philipa Hellen Prasetya1) \\ 1Jurusan Diploma Tiga Kebidanan Sekolah Tinggi Ilmu Kesehatan Prima Indonesia \\ Email : umi@stikesprimaindonesia.ac.id \\ ${ }^{2}$ Akademi Kebidanan Prestasi Agung
}

\begin{abstract}
Background The definition of exclusive breastfeeding means babies fed on breast milk, without additional other fluids such as formula milk, oranges, honey, tea water, water and without solid ingredients such as bananas, papaya, milk porridge, biscuits, rice porridge and teams (Hapsari, 2014).

The purpose of the research to find out the factors that influence the failure of Exclusive Breastfeeding at Pramuka Sari RW 08 Kelurahan Rawasari, Central Jakarta.

Methods This study uses a survey method with a quantitative approach and a cross-sectional research design and the sampling technique uses total sampling. The total sample is 82 respondents.

The results showed that there were 56 respondents (68.3\%) who did not exclusively breastfeed. The mothers who did not work were 57 respondents (69.5\%), those who managed to do IMD were 49 respondents $(59.8 \%)$, bad knowledge 51 respondents $(62.2 \%)$, husbands who did not support 49 respondents $(59.8 \%)$. There is a relationship between the failure of Exclusive Breastfeeding respondents who did not do IMD as much as 29 (35.4\%) ( $P$ value: 0.002 and OR: 5,907), respondents with bad knowledge had 45 respondents (54.9\%) ( $P$ value: $0,000$ and value OR: 13,636$)$, respondents who were not supported by husbands were 45 respondents $(54,9 \%)$ ( $P$ value: 0,000 and $O R: 22,500$ ).

Conclusion: There is a relationship of failure of Exclusive Breastfeeding with the age of 20-35 there are 6 respondents (7.3\%) (P value 0.039 and OR: 3.333), low education has 38 respondents (46.3\%) ( $P$ value: 0,000 and OR value: 11,611), respondents who did not do IMD were 29 (35.4\%) (P value: 0,002 and OR: 5,907), respondents with bad knowledge had 45 respondents $(54,9 \%)$ ( $P$ value: 0,000 and value OR: 13,636), respondents who were not supported by their husbands were 45 respondents $(54,9 \%)(P$ value: 0,000 and $O R$ : 22,500).
\end{abstract}

Keywords: Exclusive breastfeeding, husband's support, knowledge

\section{ABSTRAK}

Latar Belakang : Pengertian ASI eksklusif berarti bayi yang diberi ASI, tanpa tambahan cairan lain seperti susu formula, jeruk, madu, air teh, air putih dan tanpa maknan padat seperti pisang, pepaya, bubur susu, biskuit, bubur nasi dan tim (Hapsari, 2014).

Tujuan : Untuk mengetahui faktor-faktor yang mempengaruhi kegagalan pemberian ASI Eksklusif di Pramuka Sari RW 08 Kelurahan Rawasari, Jakarta Pusat.

Metode: Penelitian ini menggunakan metode survei dengan pendekatan kuantitatif dan desain penelitian secara cross sectional dan teknik pengambilan sampel menggunakan total sampling. Jumlah sampel 82 responden.

Hasil: penelitian yang didapatkan bahwa yang tidak menyusui secara eksklusif ada 56 responden $(68,3 \%)$. Ibu yang tidak bekerja sebanyak 57 responden $(69,5 \%)$, yang berhasil melakukan IMD sebanyak 49 responden $(59,8 \%)$, pengetahuan buruk 51 responden $(62,2 \%)$, suami yang tidak mendukung sebanyak 49 responden $(59,8 \%)$. Ada hubungan kegagalan pemberian ASI Eksklusif responden yang tidak melakukan IMD sebayak $29(35,4 \%)$ (P value: 0,002 dan OR: 5,907), responden yang berpengetahuan buruk ada 45 responden 
$(54,9 \%)$ ( $P$ value: 0,000 dan nilai OR: 13,636), responden yang tidak didukung suami sebanyak 45 responden $(54,9 \%)$ (P value: 0,000dan OR: 22,500.

Kesimpulan : Ada hubungan kegagalan pemberian ASI Eksklusif dengan pendidikan rendah ada 38 respoden (46,3\%) ( $P$ value: 0,000 dan nilai OR: 11,611), responden yang tidak melakukan IMD sebayak 29 $(35,4 \%)$ ( $P$ value: 0,002 dan OR: 5,907$)$, repsonden yang bepengetahuan buruk ada 45 responden $(54,9 \%)(P$ value: 0,000 dan nilai $O R: 13,636)$, responden yang tidak didukung suami sebanyak 45 responden $(54,9 \%)$ ( $P$ value: 0,000 dan OR: 22,500$)$.

Kata kunci: ASI ekslusif, , Pengetahuan

\section{PENDAHULUAN}

Menyusui adalah proses alami bagi
seseorang ibu untuk menghidupi dan menyejahterakan anak pasca melahirkan. Proses menyusui yang tidak mudah memerlukan kekuatan agar dapat berhasil (Riksani, 2012). Air Susu Ibu (ASI) merupakan proses nutrisi alamiah terbaik bagi bayi karena mengandung kebutuhan energy dan zat yang dibutuhkan selama enam bulan pertama kehidupan bayi. Namun, adakalanya seorang ibu mengalami masalah dalam pemberian ASI. Kendala yang utama adalah karena produksi ASI tidak lancar (Saleha, 2009).

Manfaat ASI yaitu bayi mendapatkan kekebalan tubuh serta perlindungan dan kehangatan melalui kontak kulit dengan ibunya, mengurangi perdarahan serta konservasi zat besi, protein dan zat lainnya, dan ASI Ekslusif dapat menurunkan angka kejadian alergi, terganggunya pernapasan, diare dan obesitas pada anak (Riskani, 2012). Bila bayi tidak diberi ASI Eksklusif memiliki dampak yang tidak baik bagi bayi. Adapun dampak memiliki risiko kematian karena diare 3,94 kali lebih besar dibandingkan bayi yang mendapat ASI Eksklusif (Kemenkes, 2010). Bayi yang diberi ASI akan lebih sehat dibandingkan dengan bayi yang diberi susu formula.

Pemberian ASI akan lebih sehat dibandingkan dengan bayi yang diberi susu formula. Pemberian susu formula pada bayi dapat meningkatkan risiko infeksi saluran kemih, saluran nafas dan telinga. Bayi juga mengalami diare, sakit perut (kolik), alergi makanan, asma, diabetes dan penyakit saluran pencernaan kronis (Hapsari, 2014).

Sehubungan dengan Sustainable Development Goals (SDGs) atau tujuan pembangunan berkelanjutan 2030, menyusui merupakan salah satu langkah pertama bagi seorang manusia sejahtera. Sayangnya tidak semua orang mengetahui hal ini. Dibeberapa Negara maju dan berkembang termasuk Indonesia, banyak ibu karir yang tidak menyusui secara eksklusif. Menurut UNICEF, ASI Eksklusif dapat menekan angka kematian bayi di Indonesia.

UNICEF menyatakan bahwa 30 ribu kematian anak balita di Indonesia dan 10 juta kematian balita di seluruh dunia setiap tahun dapat dicegah melalui pemberian ASI Eksklusif selama 6 bulan sejak pertama setelah kelahiran bayi tanpa memberikan makanan dan minuman tambahan kepada bayi (Prasetyono, 2009). Cakupan ASI Eksklusif di negara ASEAN seperti India mencapai $46 \%$, di Philipina 34\%, di Vietnam 27\%, di Myanmar $24 \%$ sedangkan di Indonesia sudah mencapai $54,3 \%$ (Infodatin, 2014).

Di Indonesia hampir 9 dari 10 ibu pernah memberikan ASI, namun penelitian IDAI (Yohmi dkk, 2015) menemukan hanya $49,8 \%$ yang memberikan ASI eksklusif selama 6 bulan sesuai rekomendasi WHO. Hasil penelitian di DKI Jakarta dari Program Magister Kedokteran Kerja Departemen Kedokteran Komunitas FKUI, diperoleh presentase di Jakarta yang memberikan ASI Eksklusif pada bayinya hanya $32 \%$. Bahkan $80 \%$ pekerja pabrik di Jakarta tidak memberikan ASI Eksklusif. Hal ini dipengaruhi oleh beberapa faktor dari pengetahuan, dukungan suami, keberhasilan IMD dan pekerjaan karena aktifitas kerja ibu yang berfokus kepada pencapaian karir. Hak ibu untuk memberikan ASI Eksklusif dan menyediakan fasilitas khusus untuk menyusui hak ini tertuang pada bab V pasal 30 (Hapsari, 2014).

Berdasarkan Studi Pendahuluan data yang diperoleh di Pramuka Sari RW 08 Kelurahan Rawasari Jakarta pusat, Dari jumlah 26 lbu yang memiliki bayi di dapatkan 18 orang $(69,2 \%)$ tidak memberikan ASI Ekslusif. 


\section{METODE PENELITIAN}

Penelitian ini bersifat kuantitatif, dengan metode penelitian survei analitik yang bertujuan untuk survei atau penelitian. Desain penelitian yang digunakan yaitu cross sectional yang bertujuan untuk mempelajari dinamika korelasi antara faktorfaktor resiko dengan efek dengan cara pendekatan atau pengumpulan data sekaligus pada suatu saat (Notoatmodjo, 2012).

Populasi adalah keseluruhan objek penelitian atau objek yang diteliti (Notoatmodjo, 2012). Dalam penelitian ini adalah semua ibu yang memiliki anak $>6$ bulan-2 tahun yang ada di Posyandu RW 08 kelurahan Rawasari. Jumlah populasi di Pramuka Sari RW 08 Kelurahan Rawasari Jakarta Pusat berjumlah 82 orang. Dalam penelitian ini peneliti mengambil dengan teknik total sampling yaitu dengan mengambil semua anggota populasi menjadi sampel.

HASIL DAN PEMBAHASAN

Analisis Univariat

Berdasarkan tabel 1 di dapatkan Hasil penelitian bahwa dari 82 responden yang bekerja sebanyak 25 responden (30,5\%) sedangkan ibu yang tidak bekerja sebanyak 57 responden ( $69,5 \%)$. Keberhasilan IMD yang berhasil 49 responden $(59,8 \%)$ dan tidak berhasil sebanyak 33 responden( $40,2 \%)$, Pengetahuan ibu baik sebanyak $35(42,7 \%)$ dan kurang sebanyak 35 responden ( $57,3 \%$ ), dukungan suami sebanyak 33 responden $(40,2 \%)$ dan tidak didukung suami sebanyak 49 responden $(59,8 \%)$

Tabel 1 Distribusi Frekuensi Responden berdasarkan Usia, Pendidikan Pekerjaan, Keberhasilan IMD, Pengetahuan, Dukungan Suami dan Pemberian ASI Eksklusif di RW 08

\begin{tabular}{lcc}
\hline \multicolumn{1}{c}{ Variabel } & $\mathrm{N}$ & $\%$ \\
\hline Pemberian ASI Eksklusif & & \\
Ya & 26 & 31,7 \\
Tidak & 56 & 68,3 \\
\hline Pekerjaan & & \\
Bekerja & 25 & 30,5 \\
TidTidak bekerja & 57 & 69,5 \\
\hline Keberhasilan IMD & & \\
Ya & 49 & 59,8 \\
Tidak & 33 & 40,2 \\
\hline Pengetahuan & & \\
Baik & 35 & 42,7 \\
Kurang & 47 & 57,3 \\
\hline Dukungan Suami & & \\
Mendukung & 33 & 40,2 \\
Tidak mendukung & 49 & 59,8 \\
\hline
\end{tabular}

\section{Analisis Bivariat}

Tabel 2 Hubungan Kegagalan Pemberian ASI Eksklusif dengan, Pekerjaan, Keberhasilan, Pengetahuan dan Dukungan Suami

\begin{tabular}{lcccccc}
\hline \multirow{2}{*}{ Variabel } & \multicolumn{6}{c}{ ASI Eksklusif } \\
\cline { 2 - 5 } & \multicolumn{2}{c}{$\mathrm{Ya}$} & \multicolumn{5}{c}{ Tidak } & \multirow{2}{*}{ P value } & OR \\
\cline { 2 - 5 } & $\mathrm{N}$ & $\%$ & $\mathrm{~N}$ & $\%$ & & \\
\hline Pekerjaan & & & & & & \\
Tidak Bekerja & 17 & 29,8 & 40 & 70,2 & 0,768 & 1,3 \\
Bekerja & 9 & 36 & 16 & 64 & & $(0,4-3,5)$ \\
\hline Keberhasilan IMD & & & & & & \\
\hline
\end{tabular}




\begin{tabular}{lcccccc}
\hline Tidak & 4 & 12,1 & 29 & 87,9 & 0,004 & 5,9 \\
Ya & 22 & 44,9 & 27 & 55,1 & & $(1,8-19)$ \\
\hline Pengetahuan & & & & & & \\
Kurang & 7 & 14,9 & 40 & 85,1 & 0,000 & 6,7 \\
Baik & 19 & 54,3 & 16 & 45,7 & & $(2,3-19)$ \\
\hline Dukungan Suami & & & & & & \\
Tidak Mendukung & 4 & 8,3 & 45 & 91,8 & 0,000 & 22,5 \\
Mendukung & 22 & 66,7 & 11 & 33,3 & & $(6,4-78)$ \\
\hline
\end{tabular}

Berdasarkan tabel 2 di dapatkan hasil ibu yang bekerja yang menyusui ASI Eksklusif sebanyak 9 responden (36\%) dan ibu yang tidak ASI Eksklusif dan tidak bekerja sebanyak 40 responden $(70,2 \%)$, Keberhasilan IMD pada ibu yang menyusui ASI Eksklusif sebanyak 22 Responden $(44,9 \%)$ dan tidak berhasil IMD pada ibu tidak menyusui 29 Responde $n(87,9 \%)$, Pengetahuan baik pada ibu menyusui ASI Eksklusif sebanyak 19 Responden (54,3\%) dan pengetahuan kurang pada ibu yang tidak menyusui ASI Eksklusif sebanyak 40 Responden (85,1\%), Dukungan suami pada ibu menyusui ASI Eksklusif sebanyak 4 Responden (8,3\%) dan suami yang tidak mendukung pada ibu yang tidak menyusui ASI Eksklusif sebanyak 45 Responden (91,9\%)

\section{PEMBAHASAN}

Hasil penelitian bahwa dari 82 responden yang bekerja sebanyak 25 responden $(59,8 \%)$ sedangkan ibu yang tidak bekerja sebanyak 57 responden ( 40,2\%). Responden yang bekerja tetapi tidak memberikan ASI eksklusif sebanyak 16 orang $(64 \%)$ lebih kecil dibandingkan orang yang tidak bekerja tetapi tidak memberikan ASI Eksklusif sebanyak 40 orang $(70,2 \%)$. Setelah dilakukan uji chi square didapatkan nilai $P$ value 0,768 artinya tidak ada hubungan signifikanantara pekerjaan dengan pemberiaan ASI eksklusif. Sebagian besar ibu yang tidak memberikan ASI Eksklusif ibu yang tidak bekerja dikarenakan berbagai sebab antara lain malas menyusui, takut payudara menjadi rusak.

Hal ini sejalan dengan Penelitian Hartati (2013) menunjukkan bahwa ibu yang bekerja dan memberikan ASI Eksklusif sebanyak 53,8\% sedangkan ibu yang tidak bekerja dan tidak memberikan ASI Eksklusif yaitu 52\%. Setelah dilakukan uji chi square didapatkan nilai $P$ value: 0,3533 artinya tidak ada hubungan yang cukup bermakna antara pekerjaan dengan perilaku ibu dalam pemberian ASI Eksklusif dan nilai OR: 1,803 artinya bahwa ibu yang bekerja berpeluang memberikan ASI Eksklusif 1 kali dibanding ibu yang tidak bekerja (Hartati, 2013).

Hasil penelitian bahwa dari 82 responden yang melakukan IMD sebanyak 49 responden $(59,8 \%)$ sedangkan yang mempunyai pendidikan rendah sebanyak 33 responden $(40,2 \%)$. Berdasarkan tabel 4.2 yang diperoleh diperoleh dari 82 responden, ibu yang melakukan IMD dan tidak memberikan ASI Eksklusif sebanyak 27 orang $(55,1 \%)$ lebih kecil dibandingkanibu yang tidak melakukan IMD tetapi tidak memberikan ASI eksklusif sebanyak 39 orang $(87,9 \%)$. Setelah dilakukan uji chi square didapatkan nilai $p$ value 0,002 artinya ada hubungan signifikan antara keberhasilan IMD dengan pemberian ASI eksklusif dan nilai $\mathrm{OR}=5,907$ artinya ibu yang melakukan IMD berpeluang 5 kali memberikan ASI Eksklusif dibanding ibu yang tidak melakukan IMD. Peneliti berasumsi bahwa tidak ada kesenjangan dengan penelitian yang dilakukan oleh Fika dan Syafiq (2003) di Jakarta tentang keberhasilan Inisiasi Menyusu Dini menunjukkan bahwa bayi yang diberi kesempatan untuk menyusu dini, hasilnya 8 kali lebih berhasil ASI Eksklusif (Roesli, 2012). Hasil penelitian yang dilakukan oleh Purwanti (2013) sebagian besar tidak melakukan Inisiasi Menyusu Dini sebanyak $64,1 \%$ dan yang melakukan IMD sebanyak $35,9 \%$.

Hal ini menunjukkan bahwa Inisiasi Menyusu Dini sangatlah penting untuk kesehatan bayi terutama dalam pemberian ASI Eksklusif dengan adanya kontak kulit dengan kulit segera setelah lahir dan bayi menyusu sendiri dalam satu jam pertama kehidupan lebih berhasil ASI Eksklusif (Purwanti, 2013).

Hasil penelitian bahwa dari 82 responden yang berpengetahuan baik sebesar 35 responden $(42,7 \%)$ sedangkan yang berpengetahuan rendah sebanyak 47 responden $(57,3 \%)$. lbu yang memberikan ASI Eksklusif dan berpengetahuan 
baik sebanyak 19 orang $(54,3 \%)$ lebih kecil dibandingkan ibu yang tidak memberikan ASI Eksklusif tetapi ibu yang berpengetahuan buruk sebanyak 40 orang $(85,1 \%)$. Setelah dilakukan uji chi square didapatkan nilai $p$ value 0,000 artinya bahwa ada hubungan signifikan antara pengetahuan dengan pemberian ASI Eksklusif dan nilai OR: 6,786 artinya bahwa ibu yang berpengetahuan buruk berpeluang 6 kali gagal dalam pemberian ASI Eksklusif. Hal ini peneliti berasumsi bahwa tidak ada kesenjangan yaitu dengan alasan pengetahuan yang baik didapatkan oleh ibu menyusui dari informasi yang diperoleh dari tenaga kesehatan dan informasi dari orang tua sebelumnya tentang manfaat memberikan ASI Eksklusif kepada bayinya.

Berdasarkan penelitian yang dilakukan oleh Fitria (2013) dari 78 responden, bahwa ibu yang berpengetahuan baik dan memberikan ASI Eksklusif sebanyak $65,7 \%$ tetapi ibu yang berpengetahuan buruk dan memberikan ASI Eksklusif sebanyak $60,5 \%$. Setelah dilakukan uji chi square didapatkan nilai $P$ value 0,0038 artinya ada hubungan signifikan antara pengetahuan dengan pemberian ASI Eksklusif dan nilai OR 2,931 artinya ibu yang berpengetahuan baik mempunyai peluang 2 kali untuk memberikan ASI Eksklusif (Hartati,2013).

Hasil penelitian bahwa dari 82 responden yang didukung suami sebanyak 33 orang $(40,2 \%)$ sedangkan yang tidak didukung suami sebanyak 49 orang (59,8\%). Ibu yang memberikan ASI Eksklusif dan diberikan dukungan suami sebanyak 22 orang $(66,7 \%)$ sedangkan ibu yang tidak memberikan ASI Eksklusif dan ibu yang tidak diberikan dukungan oleh suami sebanyak 45orang $(91,8 \%)$. Setelah dilakukan uji chi square didapatkan nilai $p$ value 0,010 artinya ada hubungan signifikan antara keberhasilan IMD dengan pemberian ASI Eksklusif dan nilai OR: 22,5artinya ibu yang tidak didukung oleh suami 22 kali gagal dibandingkan ibu yang didukung oleh suami.

Peneliti berasumsi bahwa tidak ada kesenjangan dengan teori yang menyatakan bahwa dukungan ayah bayi (suami) sangat dibutuhkan, Pentingnya peran ayah dalam mendukung ibu selama memberikan ASI nya memunculkan istilah breastfeeding father atau ayah menyusui. Jika ibu merasa didukung, dicintai dan diperhatikan, maka akan munculemosi positif yang akan meningkatkan produksi hormone okstitosin, sehingga produksi pun lancar. Dukungan dari suami dan keluarga untuk menenangkan atau bahkan memberikan bantuan sekecil apapun, misalkan mengangangkat bayi ke pangkuan ibu disaat disusui, dapat menimbulkan rasa percaya diri ibu. Rasa percaya diri tersebut dapat berpengaruh langsung terhadap kelancaran ASInya bisa lancar dan bahkan melimpah.Untuk itu, ibu perlu dibantu pada saat mulai proses menyusui sehingga cukup waktu bagi ibu untuk beristirahat, karena istirahat yang berkualitas, penting untuk meningkatkan kualitas ASI. Intinya, suami harus siap setiap kali ibu membutuhkan (Maryuni, 2015).

Dari hasil penelitian yang dilakukan oleh Purwanti yang menunjukkan bahwa peran suami baik dan ibu yang memberikan ASI Eksklusif sebanyak $62,9 \%$ sedangkan ibu yang tidak memberikan ASI Eksklusif sebanyak dan peran suami yang kurang baik $74,4 \%$.

Bahwa ibu yang mendapat dukungan suami berpeluang dalam pemberian ASI Eksklusif dibanding ibu yang tidak medapat dukungan suami. Hal ini ada hubungan antara pemberian ASI Eksklusif dengan peran suami (Purwanti, 2013).

\section{KESIMPULAN}

Berdasarkan hasil penelitian bahwa factor yang mempengaruhi kegagalan pemberian asi ekslusif adalah sebagian besar ibu yang tidak bekerja sebesar 40 orang $(70,2 \%)$ dengan $P$ value 0,768 yang artinya tidak ada hubungan signifikan antara pekerjaan dengan pemberian ASI Eksklusif. sebagian besar ibu tidak berhasil melakukan IMD sebesar 29 orang $(87,9 \%)$ dengan $P$ value 0,002 yang artinya ada hubungan signifikan antara keberhasilan IMD dengan pemberian ASI Eksklusif dan nilai OR: 22,5 yang artinya ibu yang tidak berhasil melakukan IMD mempunyai peluang 22 kali gagal dibandingkan ibu yang berhasil melakukan IMD. Sebagian besar pengetahuan buruk sebesar 40 orang $(85,1 \%)$ dengan $\mathrm{P}$ value 0,000 yang artinya ada hubungan signifikan pengetahuan buruk dengan pemberian ASI Eksklusif dan nilai OR: 6,7 yang artinya pengetahuan buruk 6 kali gagal dibandingkan dengan pengetahuan baik.

Sebagian besar tidak didukung oleh suami sebesar 45 orang $(91,8 \%)$ dengan $P$ value 0,000 yang artinya ada hubungan signifikan dukungan suami dengan pemberian ASI Eksklusif dan nilai 
OR: 22,5 yang artinya ibu yang tidak didukung oleh suami 22 kali gagal dibandingkan dengan ibu yang didukung oleh suami.

\section{DAFTAR PUSTAKA}

Alimul. 2012. Metode Penelitian Kebidanan \& Teknik Analis Data. Jakarta: Salemba Medika

Fitria. 2013. Hubungan Pengetahuan Sikap Ibu dan Pekerjaan Ibu dengan Pemberian ASI Eksklusif di Wilayah Kerja Puskesmas Perumnas Kota Lubuk Lingau Tahunn 2013. Jurnal Kesehatan Bina Husada, volume 9 (2)

Hapsari. 2014.Buku Pintar ASI Eksklusif. Jakara:Salsabila

Hartati. 2013. Faktor-faktor yang berhubungan dengan perilaku ibu dalam Pemberian ASI Eksklusif di Wilayah Kerja Puskesmas Pangkalan Balai Banyuasin III Tahun 2013. Jurnal Kesehatan Bina Husada, Volume 9 (2)
Maryunani. 2015. Inisiasi Menyusu Dini, ASI Eksklusif dan Manajemen Laktasi. Jakarta: TIM

Monika. 2014. Buku Pintar ASI dan Menyusui. Jakarta: Noura Books

Notoatmodjo. 2012. Metodologi Penelitian Kesehatan. Jakarta: Rineka Cipta

Purwanti. 2013. Faktor-faktor yang berhubungan dengan Pemberian ASI Eksklusif di Wilayah Kerja Puseksmas Bandar Jaya Lahat Tahun 2013. Jurnal Maternitas Bina Husada, Volume 1 (2)

Priyatno. 2008. Mandiri Belajar SPSS. Yogyakarta: Mediakom

Sutanto. 2014. Statistik Kesehatan. Jakarta: Rajawali Pers

Riksani. 2012. Keajaiban ASI (Air Susu Ibu). Jakarta: Dunia Sehat

Saleha. 2009. Asuhan Kebidanan Pada Masa Nifas. Jakarta: TIM

Syarifudin. 2009. Promosi Kesehatan Untuk Mahasiswa Kebidanan. Jakarta: TIM 